\title{
Using a SCIP-PLUS perspective to reduce the risk of SSI
}

\author{
CE Edmiston Jr', CJ Krepel, GR Seabrook \\ From International Conference on Prevention \& Infection Control (ICPIC 2011) \\ Geneva, Switzerland. 29 June - 2 July 2011
}

\section{Introduction / objectives}

Recent findings suggest that the Surgical Care Improvement Project (SCIP) a US-Based "process initiative" fails to reduce the risk of SSIs. The following evidence-based discussion proposes a SCIP-PLUS perspective for reducing risk of SSIs through enhanced antimicrobial prophylaxis and embracing innovative antimicrobial risk reduction technology.

\section{Methods}

Four risk reduction initiatives were studied, A: Impact of $\mathrm{BMI}$ on antimicrobial prophylactic dosing in general, $\mathrm{OB}$ and CT surgical patients; B: Development of standardized regimen of $\mathrm{CHG}$ preadmission cleansing to improve outcome in surgical patients; C: Efficacy of antimicrobial sutures to reduce the risk of suture contamination at wound closure and D: The impact of an innovative antimicrobial surgical glove to reduce the risk of microbial contamination following glove microperforation.

\section{Results}

A: 2-gm dosing in surgical patients failed to provide adequate tissue concentrations at $\mathrm{BMI}>30(p<0.05)$; $\mathrm{B}$ : Standardization of skin cleansing using a $2 \%$ CHG polyester cloths was effective at providing skin concentrations sufficient to inhibit/kill wound pathogens compared to non-standardized regimen $(p<0.001)$; C: Laboratory/clinical studies demonstrate that antimicrobial suture technology is effective $(p<0.05)$ at reducing the risk of suture contamination and SSI; D: Innovative antimicrobial surgical glove was effective $(p<0.001)$ at reducing bacterial passage following microperforation which can lead to wound contamination.

Surgery, Medical College of Wisconsin, Milwaukee, Wisconsin, USA

\section{Conclusion}

An effective SCIP-PLUS strategy requires multi-faceted evidence-based approach including antimicrobial dosing to compensate for BMI, thoughtful preadmission skin cleansing, use of antimicrobial suture technology at wound closure and embracing innovative antimicrobial surgical glove technology reducing the risk of bacterial passage into the surgical wound.

\section{Disclosure of interest}

None declared.

Published: 29 June 2011

doi:10.1186/1753-6561-5-S6-O55

Cite this article as: Edmiston et al:: Using a SCIP-PLUS perspective to reduce the risk of SSI. BMC Proceedings 2011 5(Suppl 6):O55.
Submit your next manuscript to BioMed Central and take full advantage of:

- Convenient online submission

- Thorough peer review

- No space constraints or color figure charges

- Immediate publication on acceptance

- Inclusion in PubMed, CAS, Scopus and Google Scholar

- Research which is freely available for redistribution

\section{() Biomed Central}

\section{() Biomed Central}

